\title{
Contesting and Resisting Environmental Gentrification: Responses to New Paradoxes and Challenges for Urban Environmental Justice
}

\author{
by Hamil Pearsall and Isabelle Anguelovski
}

\section{Temple University; Universitat Autònoma de Barcelona}

Sociological Research Online, 21 (3), 6

$<$ http://www.socresonline.org.uk/21/3/6.html>

DOI: $10.5153 /$ sro.3979

Received: 22 Mar 2016 I Accepted: 30 May 2016 I Published: 31 Aug 2016

\begin{abstract}
This paper analyzes environmental gentrification (EG), or the exclusion, marginalization, and displacement of long-term residents associated with sustainability planning or green developments and amenities, such as smart growth, public park renovations, and healthy food stores. We consider how activists, communities, and urban planners address these unjust processes and outcomes associated with EG and how these strategies compare to those used by environmental justice (EJ) activists. Our evaluation of relevant literature indicates several similarities with EJ resistance tactics, including collective neighborhood action, community organizing, and direct tactics. We also identify several different strategies enabled by certain urban environmental conditions, such as leveraging environmental policies and taking an active role in neighborhood redevelopment planning processes, collaborating with 'gentrifiers,' and creating complementary policies to manage displacement and exclusion. Our analysis indicates a need for more research on how activists can better assert the social and political dimensions of sustainability and their right to the city, and how green and sustainable cities can achieve justice and equity.
\end{abstract}

Keywords: Environmental Gentrification, Urban Environmental Justice, Sustainability, Resistance

\section{Introduction}

Despite the promise of sustainability to deliver the tripartite goal of economic growth, environmental quality, and social justice (Brundtland 1987), numerous studies have demonstrated that economic endeavors tend to dominate sustainability efforts, reinforce existing power relations, and deliver little to the marginalized and vulnerable populations who would benefit the most from a sustainable future - and who have long fought for increased access to environmental goods and services (Agyeman and Evans 2004; Sze 2006; Pearsall et al. 2012). These dynamics of exclusion often take place in the context of municipal sustainability planning and interventions, which are featured as a prominent component of and new opportunity for urban economic development. For instance, the City of New York released PlaNYC in 2007 as a comprehensive sustainability plan to facilitate population and economic growth. The City of Chicago features Sustainable Chicago 2015 as a way to create a city that 'spends less on energy use with each passing year, creates good-paying jobs in up-andcoming industries, responsibly maintains and upgrades its infrastructure, and ensures every Chicagoan has the opportunity to live a healthy and active lifestyle' (City of Chicago 2013, no pagination). This language invokes the metaphor that "a rising tide lifts all boats,' yet there is a trend of inequality that marginalizes and displaces vulnerable communities to make way for 'smart growth,' 'green space,' and other environmental amenities (Dooling 2009; Quastel 2009; Krueger and Gibbs 2008). 
gentrification (Gould and Lewis 2012), characterized by the implementation of environmental or sustainability initiatives that leads to the exclusion, marginalization, and displacement of economically marginalized residents, has been documented in cities across North America, Europe, and Asia (Quastel 2009; Pearsall 2010; Gould and Lewis 2012; Tretter 2013; Checker 2011; Sandberg 2014; Schuetze and Chelleri 2015; Anguelovski 2015a). The 'environmental' rent gap is central to the process of EG (Bryson 2013). In urban environments, environmental contamination depresses property values - up to $45 \%$ - through the inherent undesirability of living on or near a polluted site (Bryson 2013), and property values rise again following environmental remediation GamperRabindran et al. 2011). Further, throughout the US site clean-up has been associated with increases in mean household income and percentages of college-educated residents (Gamper-Rabindran and Timmins 2011). While not all environmental cleanups create gentrification (Eckerd 2011), gentrification may occur in parallel with cleanup activities, requiring planners to be attentive to socio-spatial impacts and land use conflicts (Abel and White 2011). Most recently, gentrification has also been linked to what Anguelovski 2015) has labeled 'green locally unwanted land uses' (LULUs), such as green space creation (Checker 2011), park restoration projects (Gould and Lewis 2012), bike lane infrastructure (Lugo 2015), smart growth development (Quastel 2009; Tretter 2013), and the opening of 'healthy' food stores (Anguelovski 2015a).

1.3 Opposition to urban environmental improvements seems contradictory, particularly when it comes from the long-time residents who have withstood the presence of contamination and lack of environmental amenities for decades - in other words, those who have been affected by environmental injustice (Lerner 2010; Sze 2006; Mohai et al. 2009). Recently, residents, community members, and social justice advocates have become concerned about EG processes that threaten to displace long-term residents, exclude them from the development process, or subsume planning decisions into market-based greenwashing or competitive city language. Residents, community members, and activists have opposed these EG catalysts and pressures using multiple strategies that challenge the presumed status quo of EG. In this paper, we ask: How are activists and urban planners starting to address new forms of inequities for historically marginalized residents, and how do their strategies compare to those used in environmental justice (EJ) campaigns? Anguelovski's (2015b) recent examination of tactics employed by EJ activists identifies multiple strategies, including coalition building, collective neighborhood action, community organizing, and direct or confrontational tactics, such as lawsuits or direct denunciations (i.e. of violations of environmental protection laws). Based on our analysis of literature published on EG since 2006, we find efforts to critique, contest, and resist EG have some overlap with EJ strategies, including collective neighborhood action, community organizing, and direct tactics. However, we also find a number of different strategies, such as leveraging environmental regulations and policies and taking an active role in neighborhood planning processes, collaborating with 'gentrifiers,' and advocating for complementary policy schemes. Below, we compare these strategies with EJ efforts. Our evaluation of strategies contributes to research on resistance to $E G$ and highlights the unique aspects of resistance that are enabled once urban environmental amenities and residents of neighborhoods where they are located become a central part of gentrification processes.

\section{Overlapping EG and EJ resistance strategies and tactics}

2.1 Reflecting the kinds of neighborhood collective action techniques used in EJ activism to promote local participation in neighborhood revitalization (Manzo and Perkins 2006; Saegert et al. 2002; Crisp 2013), EG activists and residents around the world have rallied together to participate in official city planning processes to voice their opinions and challenge redevelopment initiatives that are inconsistent with community needs. They attempt to influence the outcome of planning processes linked to environmental clean-up, restoration, or/and ecological projects to make them more equitable. For instance, key stakeholders spoke out against a proposed Green Corridor, to be included in part of Seoul's Urban Renaissance Master Plan, because of its top-down approach, inattention to traditional small-scale urbanization patterns in Asia, and potential for gentrification impacts (Schuetze and Chelleri 2015). During discussions of the Superfund designation of the Gowanus Canal in Brooklyn, NY, many community groups and residents participated in extensive planning meetings to show their support for the designation, despite the potential for the stigma associated with living near one of the most contaminated sites in the U.S., because of the funding and institutional support that came with the remediation of the polluted waterway (Pearsall 2013). In Austin, Texas environmental justice activists opposed the city's Smart Growth plan, successfully, by reframing the plan as creating environmental inequalities (Tretter 2013). Meaningful community engagement has been highlighted as a key component of redevelopment measures (Lubitow et al. 2015). While participation in bureaucratic channels provides one avenue for formally registering community concerns, some groups have found that their participation does not have a meaningful impact on the outcome (Rosan 2012), particularly given disproportionate power dynamics within low-income and minority communities, and may only result in a brief aside that there was opposition to the project. Also, as Checker (2014) notes, this 
type of sustained participation can be time-consuming and resource-intensive for activists and residents - and create more burden for socially vulnerable residents.

Like EJ activists, EG efforts have also extended the capacity of collective action through complementary efforts of community organizing that include community-based organizations (Scally 2012; Von Hoffman 2004; Williams 1985). In the case of EG, such organizations play an active role in building community wealth and alternative development and training schemes for vulnerable residents so that they are able to continue living in and affording the cost of living in their neighborhoods. One example is 'sustainable community development without displacement' schemes, through which long-term residents take control over community resources and develop small industrial development projects in their neighborhood. Recent research in Boston, MA reveals the creation of new types of business models that associate job creation and training, sustained income generation for long-term residents, and EJ (Anguelovski et al. forthcoming). New partnerships between nonprofits, small businesses, and residents are facilitating the creation of integrated food networks by bringing together food growers, food processors, retails, restaurants, small waste management companies, and community land trusts. Through a partnership called the Dudley Real Food Hub (DRFH), community members work together to address complex development issues, increase access to affordable land and fresh produce, provide healthier restaurants, offer healthier school food, reuse vacant lots for growing food, develop community-owned food businesses and jobs, and help create new business ventures around food waste collection, management, and recycling. This case study illustrates residents using local environmental assets to build a new community-based industrial base and to ensure economic development opportunities for families living in the neighborhood and under pressures of gentrification.

2.3 Beyond official channels, EG activists and coalitions of residents have also engaged in direct tactics, similar to those employed by EJ activists (Bandy and Smith 2005; Pellow 2001; Pellow 2007), in an effort to put pressure on government agencies and corporations. In Vancouver, opponents to the city's EcoDensity plan held protests and wrote letters to the editor in local media to voice their concerns about the lack of affordable housing and livability aspects of the plan. Though the bill ultimately passed, Rosol (2012) notes that it was contentious and that there was weak support. In response to a proposed Whole Foods grocery store in Boston, some residents created a coalition called 'Whose Food, Whose Community' and engaged in a series of protest actions to share their opposition, including hanging banners, posting comments in newspapers and online forums, and organizing town hall meetings against the opening of this 'healthy' food store (Anguelovski 2015a). These efforts to raise awareness of community concerns did not stop the opening of Whole Foods; however, arguably, they created greater visibility of the social and racial impacts associated with healthy food store siting. Food justice advocates are increasingly aware of the potential of such stores for attracting new residents and their impact on real estate prices (Cadji and Alkon 2014; Anguelovski 2016).

\section{Differing EG and EJ resistance strategies and tactics}

3.1 This section outlines three EG strategies that differ from those used in EJ activism, as they are enabled by the intertwined processes of gentrification and urban environmental change: leveraging environmental policies and participating in neighborhood redevelopment planning, collaborating with 'gentrifiers,' and utilizing complementary policy schemes. While EJ activists have used scientific studies to motivate public agencies and corporations to respond (Corburn 2005), EG activists have found ways to successfully leverage environmental policies and regulations to oppose inequitable socio-economic and environmental impacts. For instance, the addition of the Gowanus Canal in Brooklyn, NY to the Superfund National Priorities List (NPL) was a contentious issue that polarized the community around the issue of neighborhood redevelopment (Pearsall 2013). Opponents argued that it would slow the redevelopment of the long-abandoned brownfields along the banks. Supporters argued that it would allow for a thorough remediation and a formalized mechanism for ongoing community involvement in redevelopment. Ultimately, the state of New York declared the site sufficiently toxic for the designation. While the designation may have slowed the pace of gentrification in the area, Pearsall (2013) concludes that it may not change the future of redevelopment in the area. In Sweden, city ecologists were also able to use an environmental policy to improve public access to a new urban park in Malmö (Sandberg 2014), initially established as a scenic-only amenity for condominium owners situated along the perimeter of the park. By discovering unique flora and fauna, city ecologists advocated for the park to become a nature reserve with greater accessibility. These examples demonstrate that certain urban environmental features serve as driver of gentrification, yet they have policy implications that may help activists realize more equitable outcomes.

While some EG activists have used confrontational tactics, others have pursued a collaborative approach with environmental and urban planners, public officials, and local industries. A strategy coined 'Just Green Enough' (Curran and Hamilton 2012) involves the development of a partnership between the 'gentrifiers' 
and long-time residents to remediate and redevelop contaminated sites without the displacement. Curran and Hamilton (2012) observed this process in the redevelopment of Newtown Creek, an industrial waterway that was designated as a Superfund site in 2010, where they found a growing number of collaborative efforts to remediate the creek and add new amenities, such as parks and a nature walk, through formal planning efforts, and to incorporate the former industrial fabric into new economic development opportunities - rather than to eliminate industrial activities. They find that state intervention in remediation efforts provides mechanisms for meaningful community participation.

3.3 Finally, some EG activists have found that complementary policy schemes also provide an effective approach to reduce displacement potential. Anti-gentrification policies might include housing trust funds to complement community-based greening strategies with affordable housing schemes (Thompson 2015) and specific provisions for affordable housing, all of which need to be subject to stricter regulations of real estate development by public officials and planners (Wolch et al. 2014). In Boston, the community land trust held by the community organization DNI has allowed residents to control investment and development over 1,300 parcels of formerly contaminated and/or abandoned land (Anguelovski 2014). In Malmö, Sweden, Fitzgerald and Lenhart (2015) found that Eco-Districts were not associated with gentrification because city planners had an explicit goal to include low-to-moderate income housing in all districts. Further, the design and scale of green space may matter. Small-scale environmental projects may have less potential to attract large scale-development (Wolch et al. 2014), and long linear green spaces integrated with blue infrastructure and with affordable public transit systems may make access to green space more equitable over time and space (Ngom et al. 2016).

\section{Conclusions and next steps}

4.1 Urban environmental transformations and improvements are intertwined with processes that (re)produce social and environmental inequalities and gentrification, and these inequities are contested by EG activists. This analysis finds that EG tactics include established strategies from the EJ movement, as well as three different strategies that have become necessary in the context of new displacement and exclusion trends developing in the context of EG processes. Here, the environmental aspects of urban processes create opportunities for institutional thickness that provides additional state and policy support for socially just outcomes.

4.2 We call for more research on EG to better understand how activists oppose the a-political, post-political, and technocratic discourse of sustainability and reassert the social and political dimensions of the sustainability concept - and their right to the city. What does their activism mean and how is it framed in a context in which municipal sustainability projects are presented as win-win solutions for all residents? New large-scale research should examine whether greener cities are in reality less racially and socially equitable and assess the reality and magnitude of displacement within and across cities. In-depth assessments are needed to compare cities and determine which ones are more equal than others as they implement greening agendas - and for what reasons. Only by answering these questions will we as scholars, activists, and planners be able to answer whether and how green and healthy cities can also be just.

\section{References}

ABEL, T. D. and WHITE, J. (2011) 'Skewed riskscapes and gentrified inequities: Environmental exposure disparities in Seattle, Washington', American journal of public health, Vol. 101, No. S1, p. S246-S254. [doi:10.2105/AJPH.2011.300174]

AGYEMAN, J. and EVANS, B. (2004) "Just sustainability': the emerging discourse of environmental justice in Britain?', The Geographical Journal, Vol. 170, No. 2, p. 155-164. [doi:10.1111/j.00167398.2004.00117.x]

ANGUELOVSKI, I. (2014) Neighborhood as Refuge: Community Reconstruction, Place Remaking, and Environmental Justice in the City: MIT Press. [doi:10.7551/mitpress/9780262026925.001.0001]

ANGUELOVSKI, I. (2015a) 'Alternative food provision conflicts in cities: Contesting food privilege, injustice, and whiteness in Jamaica Plain, Boston', Geoforum, Vol. 58, p. 184-194.

[doi:10.1016/j.geoforum.2014.10.014] 
ANGUELOVSKI, I. (2015b) 'Tactical developments for achieving just and sustainable neighborhoods: the role of community-based coalitions and bottom-to-bottom networks in street, technical, and funder activism', Environment and Planning C: Government and Policy, Vol. 33, No. 4, p. 703-725. [doi:10.1068/c12347]

ANGUELOVSKI, I. (2016) 'Healthy Food Stores, Greenlining and Food Gentrification: Contesting New Forms of Privilege, Displacement and Locally Unwanted Land Uses in Racially Mixed Neighborhoods', International Journal of Urban and Regional Research

ANGUELOVSKI, I., BRAND, A., CHU, E. and GOH, K. (forthcoming) 'Urban Planning, Environmental Justice, and Green Gentrification', in CHAKRABORTY, J., HOLLIFIED, R. and WALKER, G. (editors) Handbook of Environmental Justice. Routledge.

BANDY, J. and SMITH, J. (2005) Coalitions across borders: Transnational protest and the neoliberal order. Rowman \& Littlefield.

BRUNDTLAND, G. H. (1987) 'World Commission on Environment and Development.(1987)',Our common future, Vol. 383.

BRYSON, J. (2013) 'The nature of gentrification', Geography Compass, Vol. 7, No. 8, p. 578-587. [doi:10.1111/gec3.12056]

CADJI, J. and ALKON, A. (2014) 'ONE DAY, THE WHITE PEOPLE ARE GOING TO WANT THESE HOUSES AGAIN', Zavestoski, $S$ and Agyeman, J (ads) Incomplete streets: Processes, practices and possibilities. London. Routledge, p. 154-175.

CHECKER, M. (2011) 'Wiped out by the "greenwave": environmental gentrification and the paradoxical politics of urban sustainability', City \& Society, Vol. 23, No. 2, p. 210-229. [doi:10.1111/j.1548-744X.2011.01063.x]

CHECKER, M. (2014) 'Green is the new brown: "Old school toxics" and environmental gentrification on a New York City Waterfront'.

CITY OF CHICAGO (2013) 'Sustainable Chicago 2015', in CITY OF CHICAGO (editor). City of Chicago,.

CORBURN, J. (2005) Street science: Community knowledge and environmental health justice The MIT Press.

CRISP, R. (2013) "Communities with oomph'? Exploring the potential for stronger social ties to revitalise disadvantaged neighbourhoods', Environment and Planning C: Government and Policy, Vol. 31, No. 2, p. 324-339. [doi:10.1068/c11122]

CURRAN, W. and HAMILTON, T. (2012) 'Just green enough: contesting environmental gentrification in Greenpoint, Brooklyn', Local Environment, Vol. 17, No. 9, p. 1027-1042. [doi:10.1080/13549839.2012.729569]

DOOLING, S. (2009) 'Ecological gentrification: A research agenda exploring justice in the city',International Journal of Urban and Regional Research, Vol. 33, No. 3, pp. 621-639. [doi:10.1111/j.14682427.2009.00860.x]

ECKERD, A. (2011) 'Cleaning up without clearing out? A spatial assessment of environmental gentrification', Urban Affairs Review, Vol. 47, No. 1, p. 31-59. [doi:10.1177/1078087410379720]

FITZGERALD, J. and LENHART, J. (2015) 'Eco-districts: Can they accelerate urban climate planning?', Environment and Planning C: Government and Policy, p. $0263774 X 15614666$.

GAMPER-RABINDRAN, S., MASTROMONACO, R. and TIMMINS, C. (2011) 'Valuing the benefits of superfund site remediation: Three approaches to measuring localized externalities'. National Bureau of Economic Research. [doi:10.3386/w16655]

GAMPER-RABINDRAN, S. and TIMMINS, C. (2011) 'Hazardous waste cleanup, neighborhood gentrification, and environmental justice: Evidence from restricted access census block data', The American Economic Review, Vol. 101, No. 3, p. 620-624. [doi:10.1257/aer.101.3.620]

GOULD, K. A. and LEWIS, T. L. (2012) 'The environmental injustice of green gentrification',The World in Brooklyn: Gentrification, Immigration, and Ethnic Politics in a Global City. Plymouth: Lexington Books, p. 113-146. 
KRUEGER, R. and GIBBS, D. (2008) "Third wave'sustainability? Smart growth and regional development in the USA', Regional Studies, Vol. 42, No. 9, p. 1263-1274. [doi:10.1080/00343400801968403]

LERNER, S. (2010) Sacrifice zones: the front lines of toxic chemical exposure in the United States Mit Press.

LUBITOW, A., ZINSCHLAG, B. and ROCHESTER, N. (2015) 'Plans for pavement or for people? The politics of bike lanes on the 'Paseo Boricua'in Chicago, Illinois', Urban Studies, p. 0042098015592823.

LUGO, A. (2015) 'Can human infrastructure combat green gentrification? Ethnographic research on bicycling in Los Angeles and Seattle', in ISENHOUR, C., G. MCDONOGH, M. CHECKER (editor) Sustainability in the Global City. New York: Cambridge University Press. [doi:10.1017/CBO9781139923316.021]

MANZO, L. C. and PERKINS, D. D. (2006) 'Finding common ground: The importance of place attachment to community participation and planning', Journal of Planning Literature, Vol. 20, No. 4, p. 335-350. [doi:10.1177/0885412205286160]

MOHAI, P., PELLOW, D. and ROBERTS, J. T. (2009) 'Environmental justice',Annual Review of Environment and Resources, Vol. 34, p. 405-430. [doi:10.1146/annurev-environ-082508-094348]

NGOM, R., GOSSELIN, P. and BLAIS, C. (2016) 'Reduction of disparities in access to green spaces: Their geographic insertion and recreational functions matter', Applied Geography, Vol. 66, p. 35-51. [doi:10.1016/j.apgeog.2015.11.008]

PEARSALL, H. (2010) 'From brown to green? Assessing social vulnerability to environmental gentrification in New York City', Environment and planning. C, Government \& policy, Vol. 28, No. 5, p. 872. [doi:10.1068/c08126]

PEARSALL, H. (2013) 'Superfund me: a study of resistance to gentrification in New York City',Urban Studies, Vol. 50, No. 11, p. 2293-2310. [doi:10.1177/0042098013478236]

PEARSALL, H., PIERCE, J. and KRUEGER, R. (2012) 'Whither Rio+ 20?: demanding a politics and practice of socially just sustainability', Local Environment, Vol. 17, No. 9, p. 935-941. [doi:10.1080/13549839.2012.724899]

PELLOW, D. N. (2001) 'Environmental justice and the political process: movements, corporations, and the state', The Sociological Quarterly, Vol. 42, No. 1, p. 47-67. [doi:10.1111/j.1533-8525.2001.tb02374.x]

PELLOW, D. N. (2007) Resisting global toxics: Transnational movements for environmental justice mit Press.

QUASTEL, N. (2009) 'Political ecologies of gentrification', Urban Geography, Vol. 30, No. 7, p. 694-725. [doi:10.2747/0272-3638.30.7.694]

ROSAN, C. D. (2012) 'Can PlaNYC make New York City "greener and greater" for everyone?: Sustainability planning and the promise of environmental justice', Local Environment, Vol. 17, No. 9, p. 959-976. [doi:10.1080/13549839.2011.627322]

SAEGERT, S., THOMPSON, J. P. and WARREN, M. R. (2002) Social capital and poor communities: Russell Sage Foundation.

SANDBERG, L. A. (2014) 'Environmental gentrification in a post-industrial landscape: the case of the Limhamn quarry, Malmö, Sweden', Local Environment, Vol. 19, No. 10, pp. 1068-1085.

[doi:10.1080/13549839.2013.843510]

SCALLY, C. P. (2012) 'Community development corporations, policy networks, and the rescaling of community development advocacy', Environment and Planning C: Government and Policy, Vol. 30, No. 4, p. 712729. [doi:10.1068/c11116]

SCHUETZE, T. and CHELLERI, L. (2015) 'Urban Sustainability Versus Green-Washing-Fallacy and Reality of Urban Regeneration in Downtown Seoul', Sustainability, Vol. 8, No. 1, p. 33. [doi:10.3390/su8010033]

SZE, J. (2006) Noxious New York: The racial politics of urban health and environmental justice MIT Press.

THOMPSON, M. (2015) 'Between Boundaries: From Commoning and Guerrilla Gardening to Community Land Trust Development in Liverpool', Antipode, Vol. 47, No. 4, pp. 1021-1042. [doi:10.1111/anti.12154] 
TRETTER, E. M. (2013) 'Contesting sustainability:'SMART growth'and the redevelopment of Austin's Eastside', International Journal of Urban and Regional Research, Vol. 37, No. 1, p. 297-310. [doi:10.1111/j.14682427.2012.01166.x]

VON HOFFMAN, A. (2004) House by house, block by block: the rebirth of America's urban neighborhoods Oxford University Press on Demand.

WILLIAMS, M. R. (1985) Neighborhood organizations: Seeds of a new urban life. Praeger Pub Text.

WOLCH, J. R., BYRNE, J. and NEWELL, J. P. (2014) 'Urban green space, public health, and environmental justice: The challenge of making cities 'just green enough", Landscape and Urban Planning, Vol. 125, p. 234-244. 